\title{
Chalcidoid parasitoids (Hymenoptera) of Actinote parapheles Jordan, 1913 (Lepidoptera: Nymphalidae)
}

\author{
Hélcio R. Gil-Santana ${ }^{1}$ \& Marcelo Teixeira Tavares $^{2}$
}

Biota Neotropica v6 (n1) - http://www.biotaneotropica.org.br/v6n1/pt/abstract?short-communication+bn01006012006

\author{
Date Received 08/04/2005 \\ Revised 11/11/2005 \\ Accepted 01/01/2006
}

\begin{abstract}
Gil-Santana, H.R. and \& Tavares, M.T. Chalcidoid parasitoids (Hymenoptera) of Actinote parapheles Jordan, 1913 (Lepidoptera: Nymphalidae). Biota Neotrop. Jan/Abr 2006, vol. 6, no. 1 http://www.biotaneotropica.org.br/v6n1/pt/ abstract?short-communication+bn01006012006. ISSN 1676-0611

Three parasitoids of Actinote parapheles Jordan 1913 (Lepidoptera: Nymphalidae), in the Superfamily Chalcidoidea (Hymenoptera) are recorded: Brachymeria mnestor (Walker 1841) (Chalcididae), Palmistichus elaiesis Delvare \& LaSalle 1993 and Tetrastichus sp. (Eulophidae).
\end{abstract}

Key words: Tetrastichinae, Nova Friburgo, Brachymerinii.

\section{Resumo}

Gil-Santana, H.R. and \& Tavares, M.T. Parasitóides Chalcidóideos (Hymenoptera) de Actinote parapheles Jordan, 1913 (Lepidoptera: Nymphalidae). Biota Neotrop. Jan/Abr 2006, vol. 6, no. 1 http://www.biotaneotropica.org.br/v6n1/pt/ abstract?short-communication+bn01006012006. ISSN 1676-0611

Três parasitóides de Actinote parapheles Jordan 1913 (Lepidoptera: Nymphalidae), pertencentes à Superfamília Chalcidoidea (Hymenoptera), são registrados: Brachymeria mnestor (Walker 1841) (Chalcididae), Palmistichus elaiesis Delvare \& LaSalle 1993 e Tetrastichus sp. (Eulophidae).

Palavras-chave: Tetrastichinae, Nova Friburgo, Brachymerinii. 


\section{Introduction}

Neotropical Acraeini butterflies (Nymphalidae: Heliconiinae) include many species common at medium to high altitudes, especially in the genus Actinote Hübner, [1819] (Lamas 2004). The American Acraeini butterflies often ingest large amounts of dehydropyrrolizidine alkaloids (PAs) from their Asteraceae hostplants in both larval and adult stages, but do not normally store these compounds for defence, instead biosynthesizing large amounts of cyanogenic glucoside linamarin in all stages (Brown Jr. \& Francini 1990). Cyanogenesis is considered a common, nonspecific and moderate defense mechanism in insects and was verified as being present in several species of Actinote including A. parapheles (Brown Jr. \& Francini 1990). Actinote parapheles Jordan 1913 is a common butterfly in Southern Brazil whose larvae feed on leaves of Mikania spp. (Asteraceae: Eupatorieae) (D’Abrera 1987, Brown Jr. 1992).

\section{Material and Methods}

Pupae of Actinote parapheles were collected by the first author in the field at the "Bela Vista” farm (22¹7’61" S - 42²9’34" W; 1090 m a.s.l.) in Nova Friburgo city, Rio de Janeiro State, Brazil in June 2004 (seven pupae) and May 2005 (three pupae).

The lepidopteran species was identified based on D’Abrera (1987) and Brown Jr. (1992) and is deposited at “Coleção Entomológica do Museu Nacional da Universidade Federal do Rio de Janeiro (MNRJ)”.

The hymenopterous species were identified based on study of type material (B. mnestor, Lectotype in Natural History Museum, London, type Hym \# 5460), Delvare \& LaSalle (1993) and Schauff et al (1997) (Tetrastichus). The chalcidoid voucher specimens are deposited in the "Coleção Entomológica do Departamento de Ciências Biológicas da Universidade Federal do Espírito Santo (UFES)”.

\section{Results and Discussion}

From the material collected in June 2004, two pupae were parasitized, and gave origin to six females of Tetrastichus sp., a male and a female of Palmistichus elaiesis Delvare \& LaSalle 1993 (Eulophidae) in one pupa, and five males and four females of $P$. elaiesis in the second pupa (Figure 1). From May 2005 one pupa was parasitized and a single female of Brachymeria mnestor (Walker 1841) (Chalcididae) emerged (Figures 2, 3). This is the first record of chalcidoid parasitoids associated with Actinote.

Brachymeria mnestor is frequently reared from many species of lepidopteran pupae in the families Ctenuchidae, Hesperiidae, Noctuidae, Papilionidae, Pieridae and Pyralidae (Noyes 2003). It is one of the most common Brachymeria species in Brazil. P. elaiesis has been recorded as parasitoid from moth pupae belonging to ten different families
(Arctiidae, Limacodidae, Lycaenidae and others) and from pupae of a chrysomelid beetle (Noyes 2003).

Godfray (1994) compiled published data about effects of secondary plant compounds on the performance of juvenile parasitoids and reinforced that all of them support the hypothesis that specific secondary compounds will have less effect on parasitoids that specialize on hosts feeding on plants containing the chemical and more effect on generalist parasitoids. B. mnestor and $P$ elaiesis are generalist parasitoids and emerged from pupae of $A$. parapheles, however it was not possible to confirm if there was any effect of host plant secondary compounds in the latter on the development of the parasitoids.

In the other hand, considering the vast amount of papers confirming the chemical defenses of several Lepidoptera groups (see Brown Jr. \& Francini 1990), future studies could be done to understand how the hymenopteran parasitoids manage to complete all their own larval phases in the immature forms of these chemically protected butterflies.

\section{Acknowledgements}

The authors thank the entomologists Carlos G. C. Mielke and Eurides Furtado for the confirmation of the identification of Actinote parapheles, and André Victor Lucci Freitas, Olaf H. H. Mielke and Francini Osses for helping with important bibliography information and comments in the last version of the manuscript.

\section{References}

BROWN JR., K.S. 1992. Borboletas da Serra do Japi: diversidade, hábitos, recursos alimentares e variação temporal. In História Natural da Serra do Japi, ecologia e preservação de uma área florestal no Sudeste do Brasil (L.P.C. Morellato, Org.). Universidade Estadual de Campinas/FAPESP, Campinas, p.142-187.

BROWN JR., K.S. \& FRANCINI, R.B. 1990. Evolutionary strategies of chemical defense in aposematic butterflies: cyanogenesis in Asteraceae-feeding American Acraeinae. Chemoecology 1:52-56.

D’ABRERA, B. 1987. Butterflies of the Neotropical Region. Part III Brassolidae, Acraeidae, Nymphalidae (partim). Victoria, Hill House, 140p.

DELVARE, G. \& LASALLE, J. 1993. A new genus of Tetrastichinae (Hymenoptera: Eulophidae) from the Neotropical region, with the description of a new species parasitic on key pests of oil palm. J. Nat. Hist. 27:435-444. 
GODFRAY, H.C.L. 1994. Parasitoids: behavioral and evolutionary ecology. Princeton University Press, Princeton.

LAMAS, G. (ed.). 2004. Checklist: Part 4A. HesperioideaPapilionoidea. Atlas of Neotropical Lepidoptera. Association for Tropical Lepidoptera/Scientific Publishers, xxxvi+439p.

NOYES, J.S. 2003. Universal Chalcidoidea Database. Avaible at: http://www.nhm.ac.uk/research-curation/projects/ chalcidoids/index.html. Access in: 07 june 2005.

SCHAUFF, M. E.; LASALLE, J. L. \& COOTE, L. D. 1997. Eulophidae. In Annotated key to genera of Neartic Chalcidoidea (Hymenoptera) (G. A. P. Gibson, J. T. Huber \& J. B. Wooley, eds.). NCR Research Press, Ottawa, p.327-429.

Title: Chalcidoid parasitoids (Hymenoptera) of Actinote parapheles Jordan, 1913 (Lepidoptera: Nymphalidae)

Authors: Hélcio R. Gil-Santana \& Marcelo Teixeira Tavares

Biota Neotropica, Vol. 6 ( number 1): 2006

http://www.biotaneotropica.org.br/v6n1/pt/ abstract?short-communication+bn01006012006

Date Received 08/04/2005 - Revised 11/11/2005 Accepted 01/01/2006

ISSN 1676-0611 


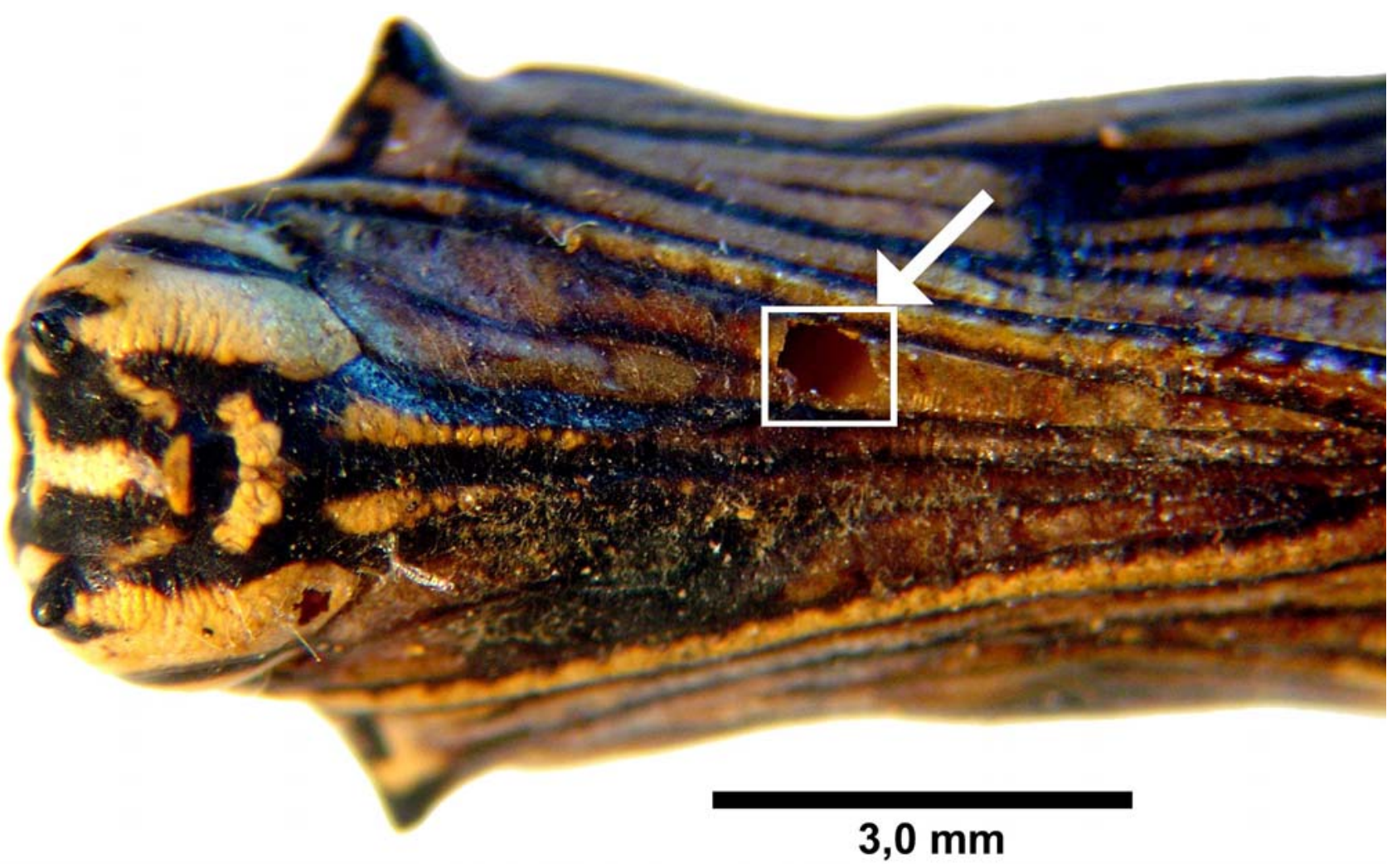

Figure 1. Pupa of Actinote parapheles showing the orifice of emergence of the Eulophidae adults (arrow), ventral view.

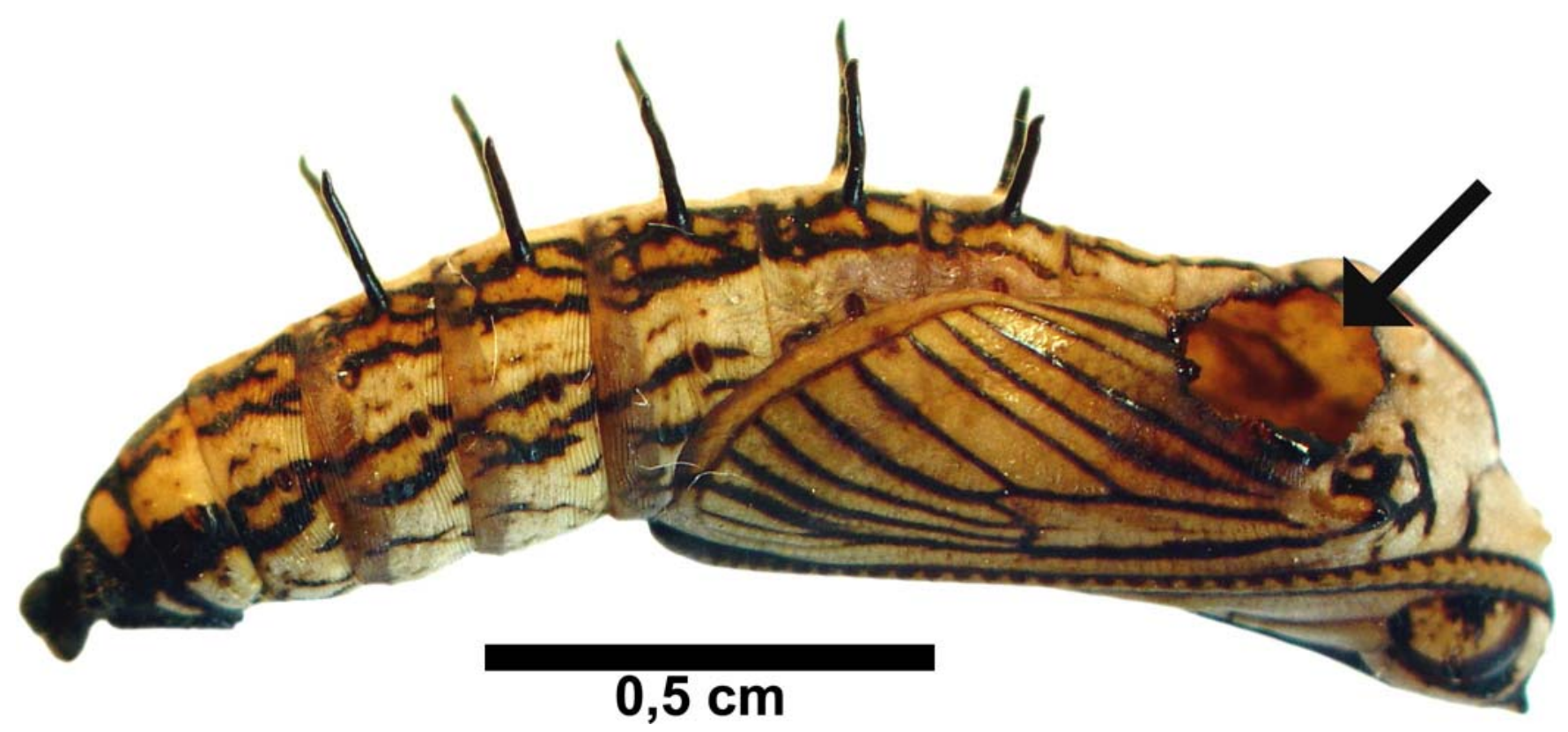

Figure 2. Pupa of Actinote parapheles after emergence of the Brachymeria mnestor adult, with the orifice indicated by the arrow, lateral view.

http://www.biotaneotropica.org.br 


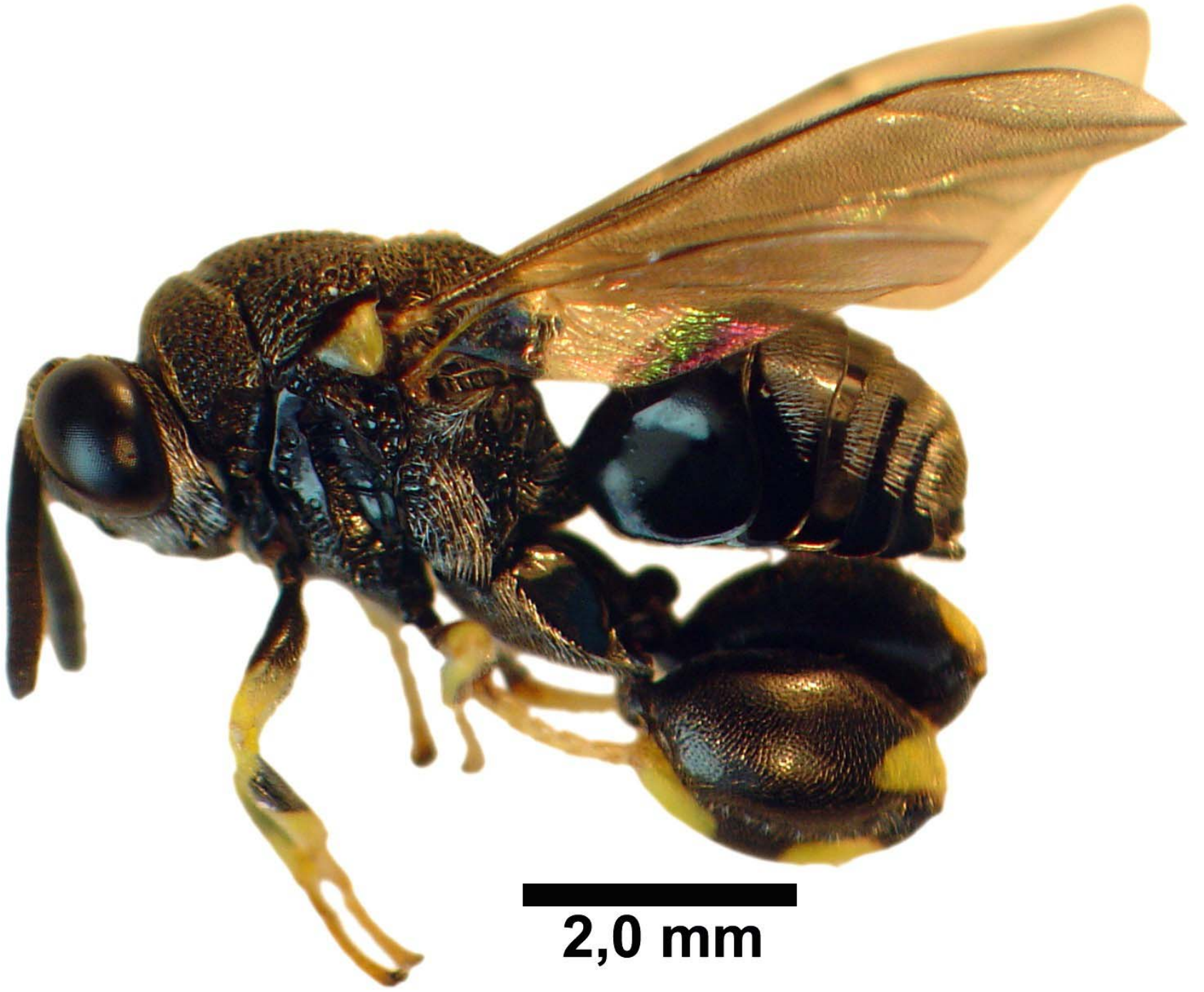

Figure 3. Adult of Brachymeria mnestor (Walker, 1841), lateral view. 